\title{
Communication \\ Chemical Characterisation of Construction and Demolition Waste in Skopje City and Its Surroundings (Republic of Macedonia)
}

\author{
Gianluca Bianchini ${ }^{1, *}$ (D) , Igor Ristovski ${ }^{2}$ (D), Igor Milcov ${ }^{2}$, Alojz Zupac $^{2}$, Claudio Natali $^{3}$ (D), \\ Gian Marco Salani ${ }^{1}$, Chiara Marchina ${ }^{1}$ (D), Valentina Brombin ${ }^{1}$ and Andrea Ferraboschi ${ }^{1}$ \\ 1 Department of Physics and Earth Sciences, University of Ferrara, Ferrara 44122, Italy; \\ slngmr@unife.it (G.M.S.); mrcchr@unife.it (C.M.); brmvnt@unife.it (V.B.); \\ andrea.ferraboschi@student.unife.it (A.F.) \\ 2 GAYA-CER Non Governmental Organization, Skopje 1000, Republic of Macedonia; \\ igor.ristovski@gmail.com (I.R.); gaja.cer.mkd@gmail.com (I.M.); alojz007@yahoo.com (A.Z.) \\ 3 Department of Earth Sciences, University of Florence, Florence 50121, Italy; claudio.natali@unifi.it \\ * Correspondence: bncglc@unife.it
}

Received: 11 February 2020; Accepted: 6 March 2020; Published: 7 March 2020

\begin{abstract}
In the Republic of Macedonia, construction and demolition (C\&D) waste is often dumped, underestimating the potential recycling and re-use as raw materials for civil engineering works and/or cement/ceramic industries. SAMCODE (Sustainable Approach to Managing Construction and Demolition Waste) is a know-how exchange program, the focus of which is chemical characterisation in terms of major and trace elements in order to evaluate the possible Macedonian C\&D waste recycling. Thirty-nine C\&D waste samples were collected from different dumps in Skopje and surroundings. $\mathrm{X}$-ray fluorescence analyses, carried out on powdered samples, show i) highly variable concentrations, indicative of the heterogenous nature of C\&D waste, and ii) high concentration in $\mathrm{Cr}, \mathrm{Ni}$, and $\mathrm{Zn}$ with respect to Italian, Chinese, and Dutch tolerance limits, probably due to the presence of these elements in ophiolitic rocks and sulphide-bearing deposits, used as raw material in building activity. Inductively coupled plasma mass spectrometry analyses of leachates, performed to assess the mobility of heavy metals, show significant concentrations of $\mathrm{Cr}$, and to a lesser extent, Ni. Results suggest that homogenisation processes of the recycled materials should be implemented and preliminary screening of $C \& D$ waste should be performed to eliminate heavy metals-bearing components.
\end{abstract}

Keywords: C\&D waste; Republic of Macedonia; chemical characterisation; recycling; heavy metals; tolerance limit

\section{Introduction}

Construction and demolition (C\&D) waste is the solid debris resulting from municipal activities. It is a heterogenous mixture of materials arising from site clearance, excavation, construction, renovation, and demolition. C\&D waste potentially includes concrete, bricks, tiles, bituminous mixtures, gypsum, wood, glass, metals, plastic, solvents, asbestos, and excavated soils. The non-hazardous inert fraction, which is the most abundant [1-3], may be recycled, resulting in substantial economic and environmental benefits. For example, after valorisation processes, the obtained $C \& D$ secondary products could be used in civil engineering applications, in substitution or in combination with non-renewable natural mineral resources (i.e., sand and gravel [4]), as well as for cement/ceramic production [5]. Therefore, proper management of $C \& D$ recycled materials can have major benefits in terms of sustainability. For this reason, the European Commission approved the Waste Framework Directive 2008/98/EC aimed at recovering $70 \%$ of construction and demolition waste by 2020 [6] in the 28 member states of the 
European Union (EU). Unfortunately, in some non-EU countries, such as the Republic of Macedonia, $C \& D$ recycling awareness is not developed yet. In the Republic of Macedonia, during building renovation, many citizens dump broken bricks, tiles, concrete elements, and plasters. According to the Macedonian landfill operator "Drisla", the estimated amounts of C\&D waste stored in the dump sites of Skopje city and its surroundings approach 150,000 tons/year. The situation in this country is alarming considering that $C \& D$ waste compositions are unknown and could potentially be hazardous for human health if asbestos or metal-bearing compounds are widespread. In addition, the irregular dumping of C\&D waste has significant environmental impacts, degrading roads and public places, ruining the landscape and precluding appropriate land management. On the other hand, C\&D waste material presents positive reuse potential, whenever it is properly separated and transformed into new raw material. Recycling C\&D waste is not simple as for many other waste materials (i.e., paper, glass, plastic, and metals), since $C \& D$ waste consists of a mixture of materials characterised by different natures and compositions. Recycling C\&D waste is very dependent on local markets, since the materials are usually not traded, and transported over long distances because of its limited value, nonetheless their potential reuse is still a matter of great importance because of the large production rate (often $>500 \mathrm{~kg} /$ person/year [7]). On this basis, the Central European Initiative (CEI) funded the SAMCODE (Sustainable Approach to Managing Construction and Demolition Waste) project, a know-how exchange programme (KEP) among the non-governmental organisation (NGO) for environmental protection GAYA-CER of Skopje, the Institute for Research in Environment, Civil Engineering and Energy (IECE) of Skopje, and the Department of Physics and Earth Sciences of the University of Ferrara (Italy). This project was dedicated to the chemical characterisation of C\&D waste, collected in dump sites in Skopje city (having more than 600,000 habitants), the capital of the Republic of Macedonia, and its surroundings, in order to: i) identify hazardous and non-hazardous waste, and ii) help to develop an integrated model for solid waste management in the Republic of Macedonia, and in other countries where the waste collection is insufficient [8]. In this framework, the present research aims at characterising C\&D waste samples on the basis of the major and trace elements composition, following the analytical methods used by Bianchini et al. [5] and Limbachiya et al. [9], and to define the potential release of hazardous heavy metals in the environment in order to evaluate their possible recycling. The preliminary analyses performed in this work show a heterogeneous nature of the Macedonian C\&D materials, as well as enrichments in $\mathrm{Cr}$ and Ni, probably due to the presence of these elements in rocks, used as raw material in Macedonian building activities. Such results suggest that in order to foresee effective recycling, a preliminary screening of Macedonian C\&D waste should be performed to eliminate heavy metals-bearing components, and that sorting and grading processes are necessary for a better homogenisation of the recycled materials. Research must be reiterated with a more statistically representative sample population, and also involve mineralogical investigation by X-ray diffraction and scanning electron microscopy, which provide complementary information.

\section{Census of Dump Sites in the Skopje City and its Surroundings and C\&D Waste Sampling}

NGO GAYA-CER carried out a census of 57 C\&D dump sites in 16 municipalities of Skopje city and its surroundings (Figure 1), and sampled around $10 \mathrm{~kg}$ of $C \& D$ waste from each site. Macroscopic plastic, paper, wood, and metal pieces were eliminated on site. The remaining material consisting in a mixture, mainly constituted by bricks, tiles, ceramics, glass, concrete, and rock blocks, was collected from 39 sites (trying to preserve the site representativity) to be processed for chemical characterisation. Friable debris made of asbestos, such as roof and floor tile and sheet fragments have been neither observed nor collected. Sampling coordinates and the amount of dumped C\&D material collected from each site are reported in Table S1. 

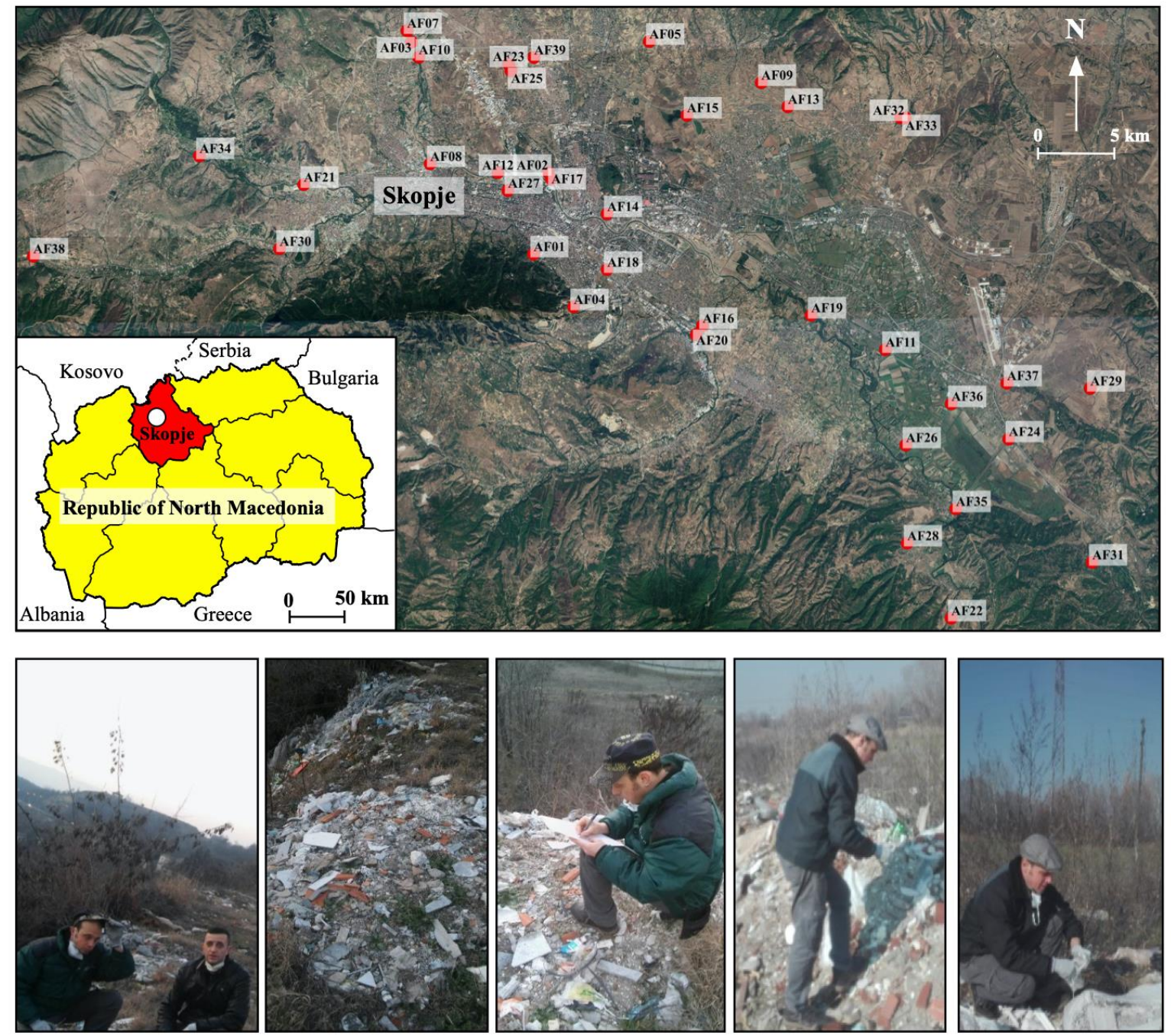

Figure 1. Location and photos of the sampling sites in Skopje city and its surroundings (Republic of Macedonia).

\section{Analytical Methods}

NGO GAYA-CER operators crosschecked the collected materials in the lab to verify the absence of friable debris related to asbestos containing materials (ACM) and then crushed the C\&D materials down to the grain size of two millimetres at the IECE laboratories. Crushed samples were quartered and enveloped in plastic bags. Samples were subjected to a test of radioactivity in the Laboratory of Radioecology of the Macedonian Institute of Public Health. The specific activity of each investigated radionuclides was measured by gamma spectrometry, according to the method IEC1452. ${ }^{40} \mathrm{~K}$ was in the range of $390-426 \mathrm{~Bq} / \mathrm{kg}$, ${ }^{226} \mathrm{Ra}$ was in the range of $28.9-31.9 \mathrm{~Bq} / \mathrm{kg}$, and ${ }^{232} \mathrm{Th}$ was in the range of 33.5-35.3 Bq $/ \mathrm{kg}$. These values are within the range of Macedonian natural soils and can be considered geogenic, i.e., specifically related to the outcropping lithologies [10,11]. At the University of Ferrara enveloped C\&D chips were firstly inspected using a binocular microscope and then powdered with an automatic agate mill and analysed at the Department of Physics and Earth Sciences of the University of Ferrara (Italy). Carbon and nitrogen analyses (expressed in wt.\%) were carried out with an Elementar Soli TOC cube in compliance with the German Institute for Standardization-DIN 19539 standard, a temperature dependent method allowing the speciation of organic and inorganic fractions [12]. Major (expressed in oxide wt.\%) and trace elements (expressed in $\mathrm{mg} / \mathrm{kg}$ ) were determined on pressed powder pellets by wavelength dispersive X-ray fluorescence spectrometry (WDXRF) using an ARL Advant-XP spectrometer, following the full matrix correction method proposed by Lachance 
and Traill [13]. Accuracy is generally lower than 2\% for major oxides and less than $5 \%$ for trace element determinations, whereas the detection limits for trace elements ranges from 1 to $2 \mathrm{mg} / \mathrm{kg}$. Volatile contents were determined by loss on ignition (LOI) at $1000^{\circ} \mathrm{C}$. Subsequently, leaching tests were performed on a sub-set of samples that showed high heavy metals concentration to assess the elemental mobility. The adopted leaching protocol was modified from the UNI EN 12457-Part 2 (2004) methodology ("Characterisation of waste-leaching-compliance test for leaching of granular waste materials"): $1 \mathrm{~g}$ of C\&D waste powder was soaked with $10 \mathrm{ml}$ of deionised water for $24 \mathrm{~h}$ and the obtained solution was centrifuged at $3000 \mathrm{rpm}$ for $10 \mathrm{~min}$ and filtered at $45 \mu \mathrm{m}$ (Minisart®NML syringe cellulose acetate filters). Composition of leachates (expressed in $\mathrm{mg} / \mathrm{l}$ ) was obtained by inductively coupled plasma mass spectrometry (ICP-MS) using a Thermo X-series spectrometer instrument on samples previously diluted 1:5 by deionised Milli-Q water (resistivity of ca. 18.2 M $\Omega$ $\times \mathrm{cm}$ ). Instrumental calibration was carried out using certified solutions and a known amount of Re and Rh was also introduced in each sample as an internal standard. Accuracy and precision were determined using several international reference standards, being lower than $10 \%$ of the measured value, with detection limits in the order of $0.001 \mathrm{mg} / \mathrm{l}$.

\section{Results and Discussion}

The total carbon (TC), organic carbon (TOC), inorganic carbon (TIC), and nitrogen (TN) contents are reported in Table S2 and Figure 2. The C\&D waste samples are characterised by TC ranging from 0.89 to $10.21 \mathrm{wt} . \%$ and TN from 0.02 to 0.39 wt.\%. For most samples the TOC values (0.30-3.34 wt.\%; Figure 2a) are lower than those of TIC (0.45-9.12 wt.\%; Figure 2a), indicating that the investigated material includes a high amount of inorganic matter (e.g., concrete, mortar, and carbonate lithologies). Only eight samples have TOC values (1.81-3.03 wt.\%; Figure 2a) higher than those of TIC (0.81-2.64 wt.\%; Figure 2a), reflecting the significant presence of organic matter or derivate materials (e.g., asphalt, plastic, and wood). Noteworthy for all samples is that TOC contents are positively correlated with TN (Figure 2b), indicating the presence of "fresh" biologically reactive organic matter [14].

The major and trace element compositions of C\&D waste samples are reported in Table S3. The obtained results show a high variability of both major and trace elements due to the heterogeneous nature of the collected materials. The highest concentrations are always related to $\mathrm{SiO}_{2}(15-60 \mathrm{wt} . \%)$, which is present in silicatic aggregates (e.g., quartz and feldspar-bearing sands), used in concrete and mortars, $\mathrm{CaO}$ (7-37 wt.\%) from lime, gypsum, and cementiferous binders, as well as from carbonate lithologies, $\mathrm{Al}_{2} \mathrm{O}_{3}(4-16 \mathrm{wt} . \%)$ and $\mathrm{K}_{2} \mathrm{O}(0.4-2.7 \mathrm{wt} . \%)$ from bricks, tails, ceramics, and soils containing clay minerals. In the binary diagrams of Figure 3 , positive or negative correlations among oxides reflect the prevalent mineralogy of the investigated $\mathrm{C} \& \mathrm{D}$ materials. According to the negative correlations between $\mathrm{CaO}$ and $\mathrm{SiO}_{2}$ (Figure $3 \mathrm{a}$ ), $\mathrm{CaO}$ and $\mathrm{Al}_{2} \mathrm{O}_{3}$ (Figure 3b), the positive correlation between $\mathrm{Al}_{2} \mathrm{O}_{3}$ and $\mathrm{K}_{2} \mathrm{O}$ (Figure $3 \mathrm{c}$ ), and the relative oxides abundances, the dominant mineral phases are quartz, followed by carbonates and aluminiferous silicatic minerals. The positive correlation between $\mathrm{CaO}$ and LOI (a parameter for the estimation of volatiles, including $\mathrm{CO}_{2}$; Figure 3d) confirms the significant presence of carbonate.

The prevalence of $\mathrm{SiO}_{2}, \mathrm{CaO}$, and $\mathrm{Al}_{2} \mathrm{O}_{3}$ on the other major oxides suggests the possible recycling of the collected $\mathrm{C} \& \mathrm{D}$ wastes in the cement industrial processes, since these oxides are the main chemical components of Portland cement [15]. However, the high $\mathrm{SiO}_{2}$ and $\mathrm{Al}_{2} \mathrm{O}_{3}$ contents hamper the sample compositions to plot in the sub-triangle $C_{3} S, C_{2} S$, and $C_{3} A$, which encloses the ideal cementstone compositions (Figure 4a; [15]). Therefore, the investigated C\&D samples must be treated (e.g., blended with lime) before being employed as raw material component in cement preparation. C\&D waste samples could be suitable also as raw materials for ceramic production (majolica, "cottoforte", and stoneware), but they should be properly treated in order to increase the amount of clay minerals with respect to the carbonatic and other silicatic phases (Figure 4b,c; [16]). In any case, it is important to state that the actual re-use of these C\&D waste in cement and/or ceramic industrial processes is hampered by the lack of homogeneous nature of the materials, as demonstrated by the scattered distributions in 
Figures 3 and 4 . The homogeneity of waste material composition is a primary feature required by the recycling process, that can only be obtained if the C\&D waste are treated in situ by proper sorting and grading [7].

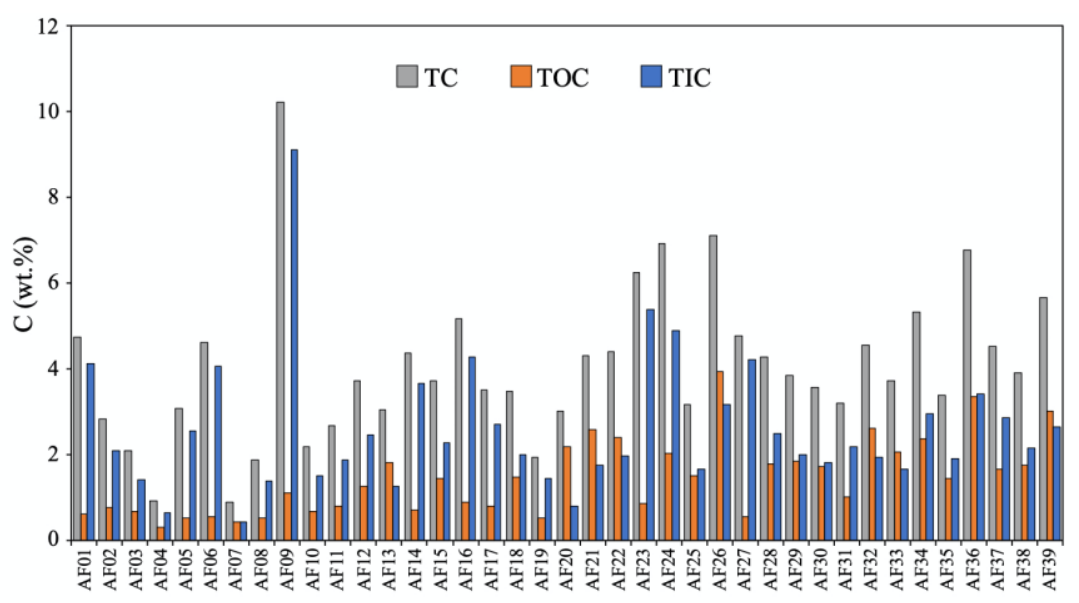

(a)

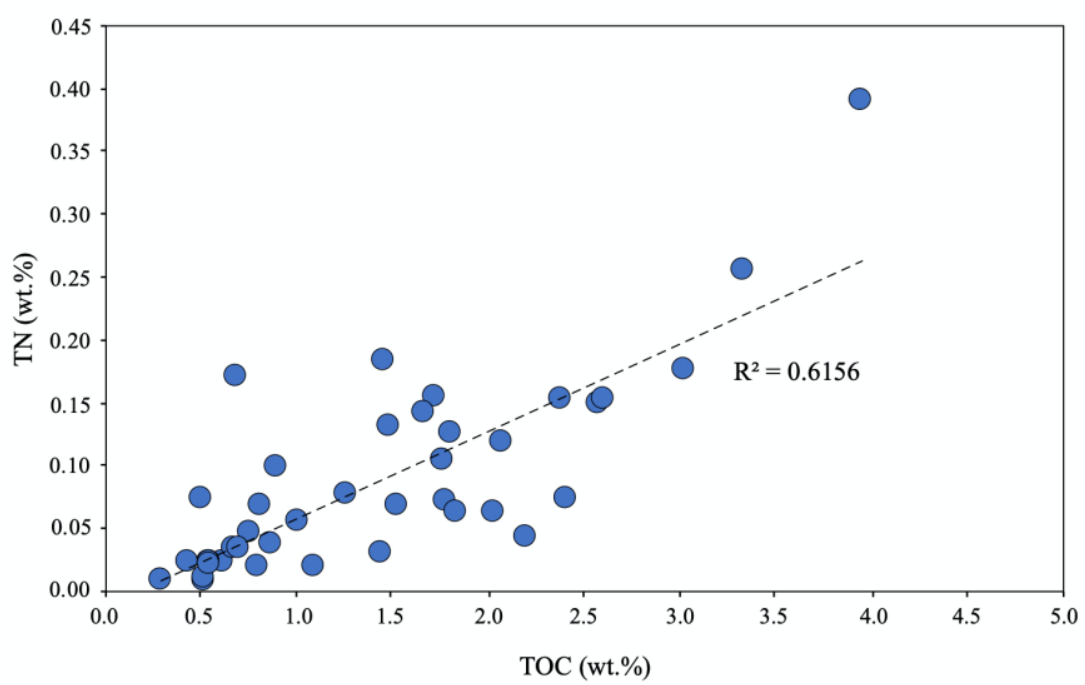

(b)

Figure 2. (a) Carbon elemental compositions of the different carbon fractions: Total carbon (TC), organic carbon (TOC), inorganic carbon (TIC) in the C\&D waste samples; (b) distribution of TOC vs total nitrogen $(\mathrm{TN})$ of the $\mathrm{C} \& \mathrm{D}$ waste samples. 


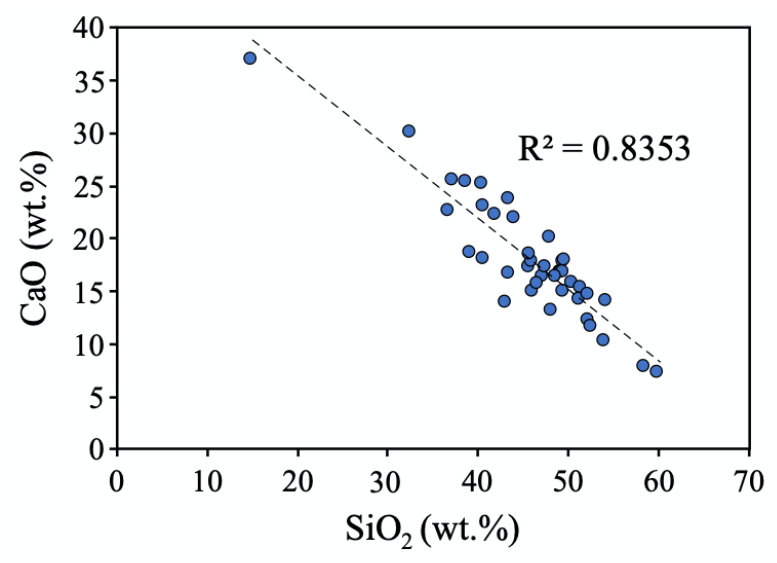

(a)

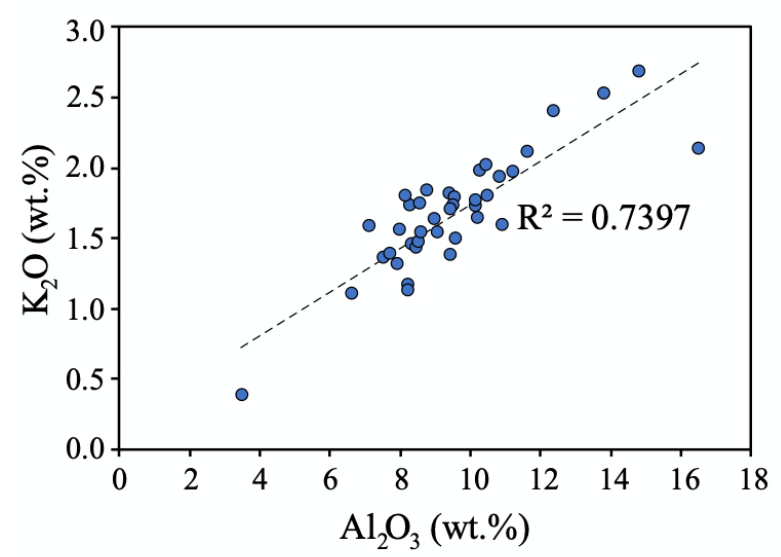

(c)

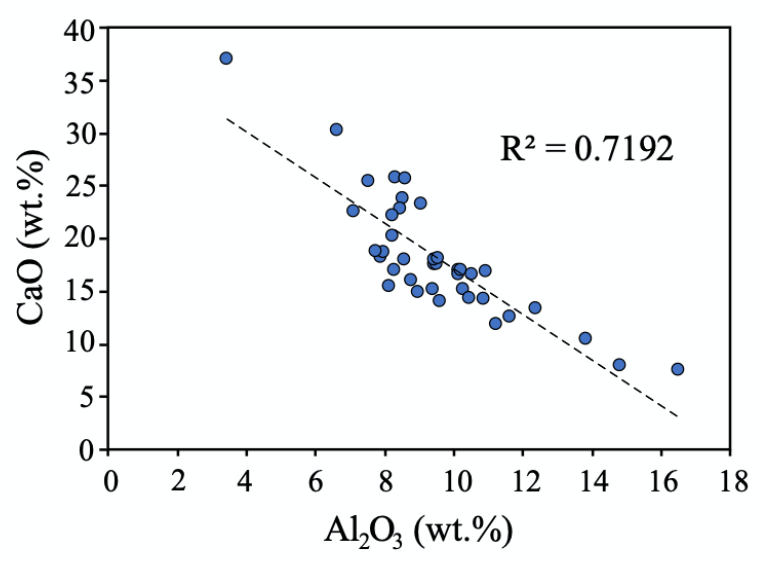

(b)

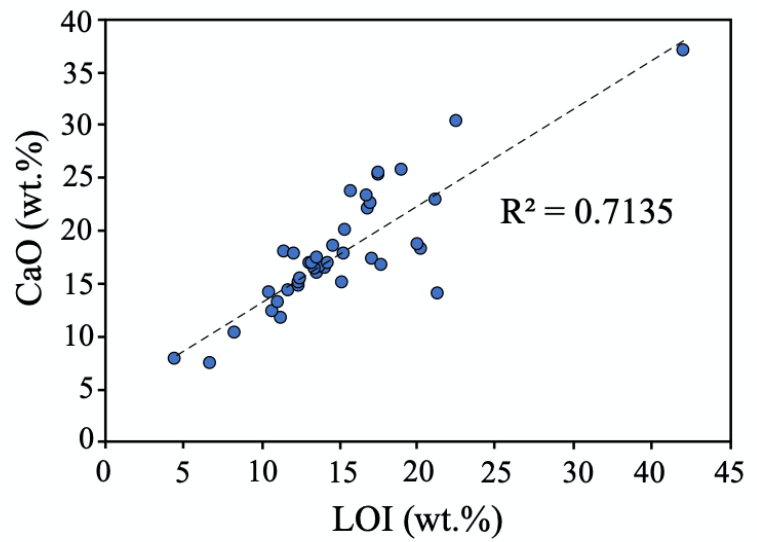

(d)

Figure 3. Distribution of (a) $\mathrm{SiO}_{2}$ vs $\mathrm{CaO}$; (b) $\mathrm{CaO}$ vs $\mathrm{Al}_{2} \mathrm{O}_{3}$; (c) $\mathrm{K}_{2} \mathrm{O}$ vs $\mathrm{Al}_{2} \mathrm{O}_{3}$; (d) $\mathrm{CaO}$ vs $\mathrm{LOI}$ of the C\&D waste samples. 


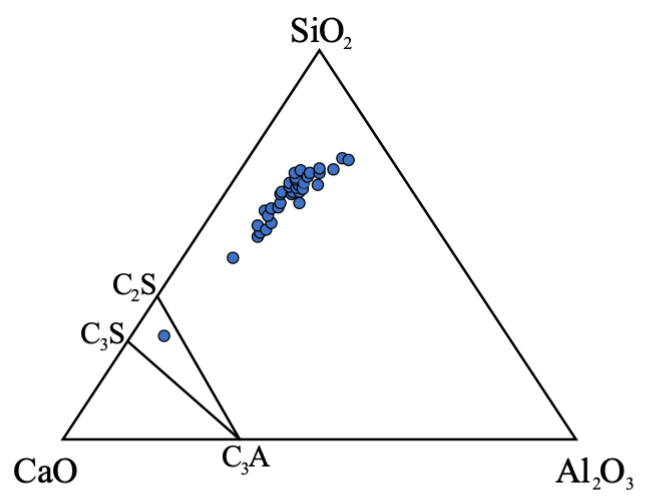

(a)

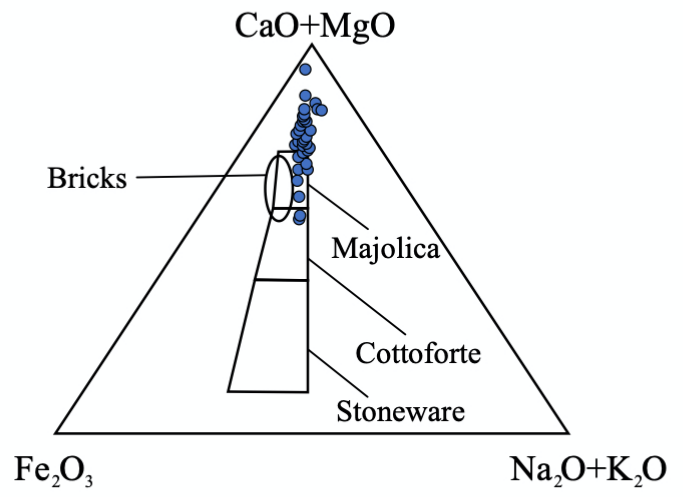

(b)

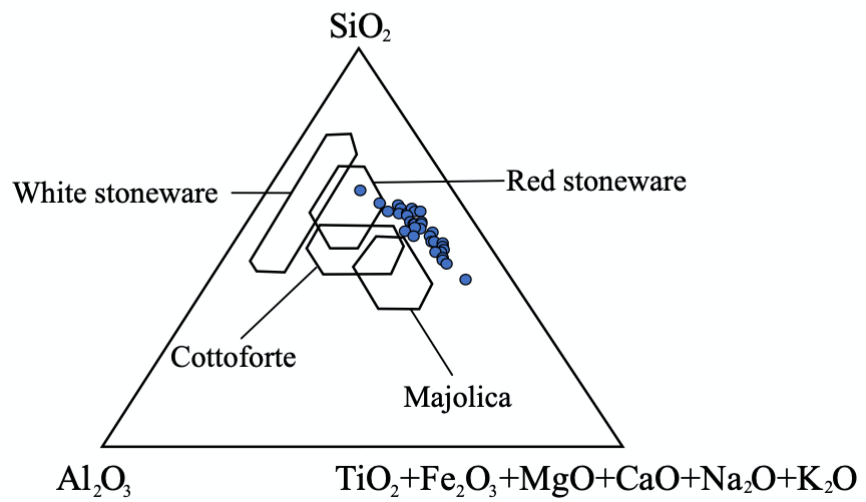

(c)

Figure 4. (a) $\mathrm{CaO}-\mathrm{Al}_{2} \mathrm{O}_{3}-\mathrm{SiO}_{2}$ triangular diagram reporting compositions of the investigated $\mathrm{C} \& \mathrm{D}$ waste samples as well as the sub-triangle $\mathrm{C}_{3} \mathrm{~S}$ (tricalcium silicate; alite)- $\mathrm{C}_{2} \mathrm{~S}$ (dicalcium silicate; belite) $-\mathrm{C}_{3} \mathrm{~A}$ (tricalcium aluminate) for the ideal cementstone compositions [15]; (b) $\mathrm{Fe}_{2} \mathrm{O}_{3}-\left(\mathrm{Na}_{2} \mathrm{O}+\right.$ $\left.\mathrm{K}_{2} \mathrm{O}\right)-(\mathrm{CaO}+\mathrm{MgO})$ triangular diagram reporting compositions of the investigated C\&D waste samples as well as compositional fields typical of ceramics (majolica, "cottoforte", and stoneware; [16]) and bricks [17]; (c) $\mathrm{Al}_{2} \mathrm{O}_{3}-\left(\mathrm{TiO}_{2}+\mathrm{Fe}_{2} \mathrm{O}_{3}+\mathrm{MgO}+\mathrm{CaO}+\mathrm{Na}_{2} \mathrm{O}+\mathrm{K}_{2} \mathrm{O}\right)-\mathrm{SiO}_{2}$ triangular diagram reporting compositions of the investigated $\mathrm{C} \& \mathrm{D}$ waste samples as well as compositional fields typical of ceramics (majolica, "cottoforte", white stoneware, and red stoneware; [16]). 
The trace elements composition (Table S3) plotted in Figure 5 emphasised a critical aspect: C\&D waste samples commonly contain anomalously high concentrations of heavy elements $(\mathrm{Co}, \mathrm{Cr}, \mathrm{Cu}$, $\mathrm{Ni}, \mathrm{Pb}, \mathrm{V}$, and $\mathrm{Zn}$ ), which are potentially hazardous for human health [18]. In fact, buildings might be repositories of pollutants of anthropogenic origin, including heavy metals [19]. Once building materials become C\&D waste, they will be a potential source of contamination [20]. In particular, when contaminated wastes are stored in dump sites, they may bring potential environmental risks to the subsurface system, accumulating in topsoil and contaminating groundwater [20]. Nowadays, there are still not threshold values of heavy metals (TVHM) for solid wastes, therefore TVHMs for soils are commonly used to assess the potential hazard of contamination [20,21]. In the absence of soil quality TVHM values in the Republic of Macedonia, the obtained results for $\mathrm{Co}, \mathrm{Cr}, \mathrm{Cu}, \mathrm{Ni}, \mathrm{Pb}, \mathrm{V}$, and $\mathrm{Zn}$, were compared with i) the Italian TVHM for soils of green areas for public/private residential purpose (Italian Legislative Decree 152, 03/04/2006 [22]), ii) the Chinese TVHM for environmental quality standard soils "Level-II", to guarantee agriculture and human health (CEPA-Chinese Environmental Protection Administration, GB 15618-1995 [23]), and iii) the target values of environmental quality Dutch standards, beyond which soils are considered contaminated (Dutch Soil Remediation Circular 2009, ESdat [24]) (Table S3). For the heavy metals considered in this study, there are some C\&D waste samples that have element concentrations higher than all the compared Italian, Chinese, and Dutch TVHMs (Figure 5), with the exception of Co, which is always lower than the Chinese TVHM (Figure 5a). The most worrying concentrations of potentially hazardous elements for human health and environment are those of $\mathrm{Cr}, \mathrm{Ni}$, and $\mathrm{Zn}$, since the majority of $\mathrm{C} \& \mathrm{D}$ waste samples plot above the Italian, Chinese, and Dutch TVHM limits (Figure 5b,d,g).

It is important to state that the high concentrations of $\mathrm{Cr}, \mathrm{Ni}$, and $\mathrm{Zn}$ do not necessarily recall the presence of anthropogenic contaminants, as these elements can be present in natural raw materials used in the country. It is noteworthy that in the Republic of Macedonia, there are rocks included in ophiolite sequences such as peridotites, serpentinites, pyroxenites, and chromitites $[25,26]$ that can contain thousand(s) $\mathrm{mg} / \mathrm{kg}$ of $\mathrm{Cr}$ and $\mathrm{Ni}$, and also mining areas bearing $\mathrm{Zn}$-sulphide (e.g., sphalerite: $\mathrm{ZnS}$ ) [27]. If similar rocks are used as raw materials in the building activity, it is not strange to have $\mathrm{C} \& \mathrm{D}$ waste anomalously enriched in $\mathrm{Cr}, \mathrm{Ni}$, and $\mathrm{Zn}$. This hypothesis is also confirmed by the literature, highlighting that the heavy metal enrichments in soils in the Republic of Macedonia, including those in the Skopje region, are geogenic in nature [28-30]. Coherently, in the Cr-Ni binary diagram (Figure 6) the $C \& D$ waste samples fall into the average Skopje soil composition field. Comparing the $\mathrm{Cr}-\mathrm{Ni}$ contents of C\&D waste samples with those of ultrafemic and gabbroic rocks from ophiolitic complexes outcropping in the Republic of Macedonia [25,26], C\&D waste samples have lower $\mathrm{Cr}-\mathrm{Ni}$ contents than the ultrafemic rocks, but similar contents to those of gabbros. These relations confirm the geogenic nature of the $\mathrm{Cr}-\mathrm{Ni}$ enrichments in C\&D waste. Further investigation, including mineralogical analyses by $\mathrm{X}$-ray diffraction and scanning electron microscopy, would be necessary to provide additional constraints. 


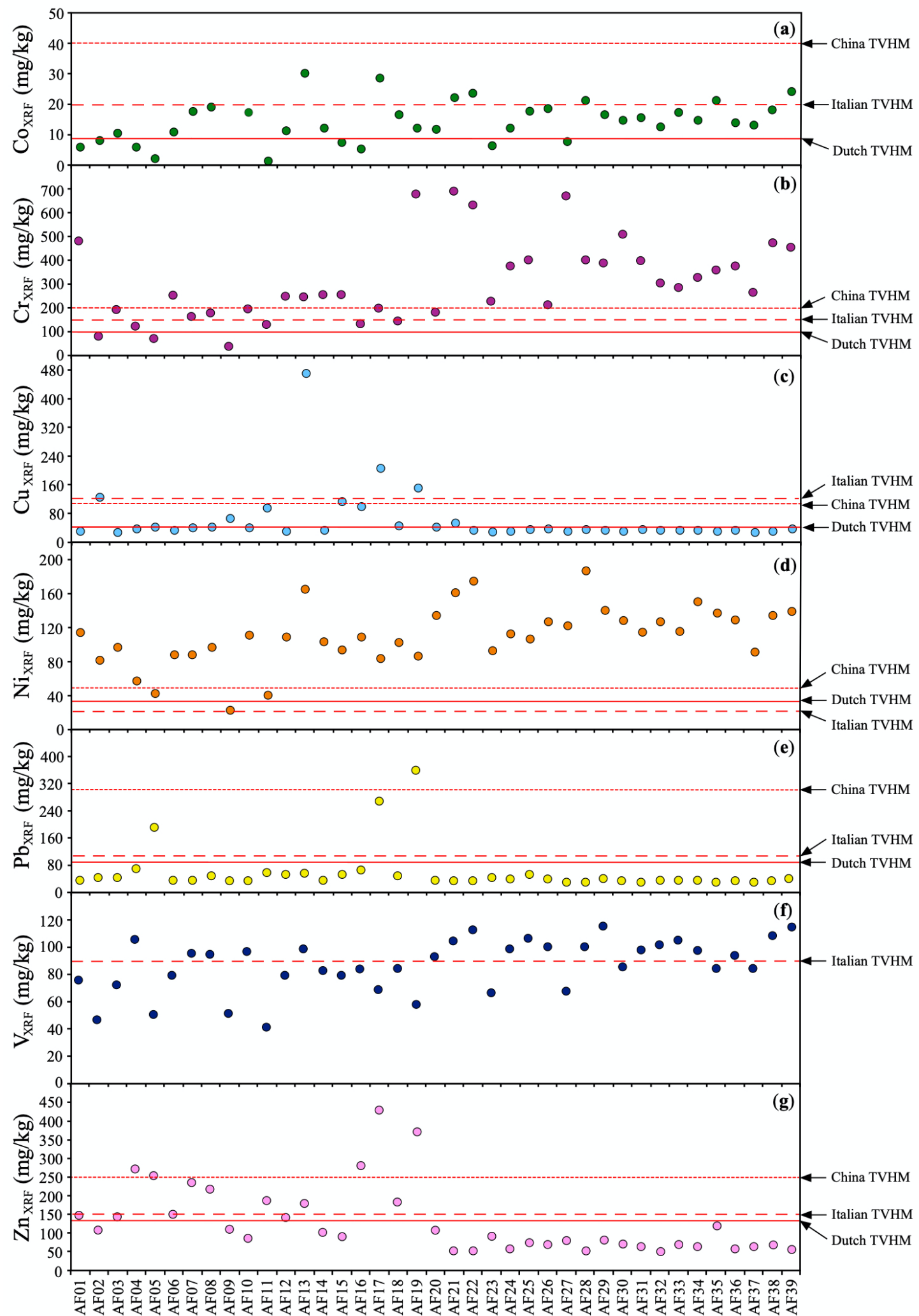

Figure 5. Concentrations in $\mathrm{mg} / \mathrm{kg}$ of (a) $\mathrm{Co}$; (b) $\mathrm{Cr}$; (c) $\mathrm{Cu}$; (d) $\mathrm{Ni}$; (e) $\mathrm{Pb}$; (f) V; (g) $\mathrm{Zn}$ in $\mathrm{C} \& \mathrm{D}$ waste samples compared with Italian, Chinese, and Dutch threshold values of heavy metals (TVHM, Table S3). Italian TVHMs (thick dashed line) are from soils of green areas used for public/private residential purposes (Italian Legislative Decree 152, 03/04/2006 [22]); Chinese TVHMs (thin dashed line) are from environmental quality standard soils "Level-II", to guarantee agriculture and human health (CEPA—Chinese Environmental Protection Administration, GB 15618-1995 [23]); Dutch TVHMs (continuous line) are the target values from environmental quality Dutch standards, beyond which soils are considered contaminated (Dutch Soil Remediation Circular 2009, ESdat [24]). 


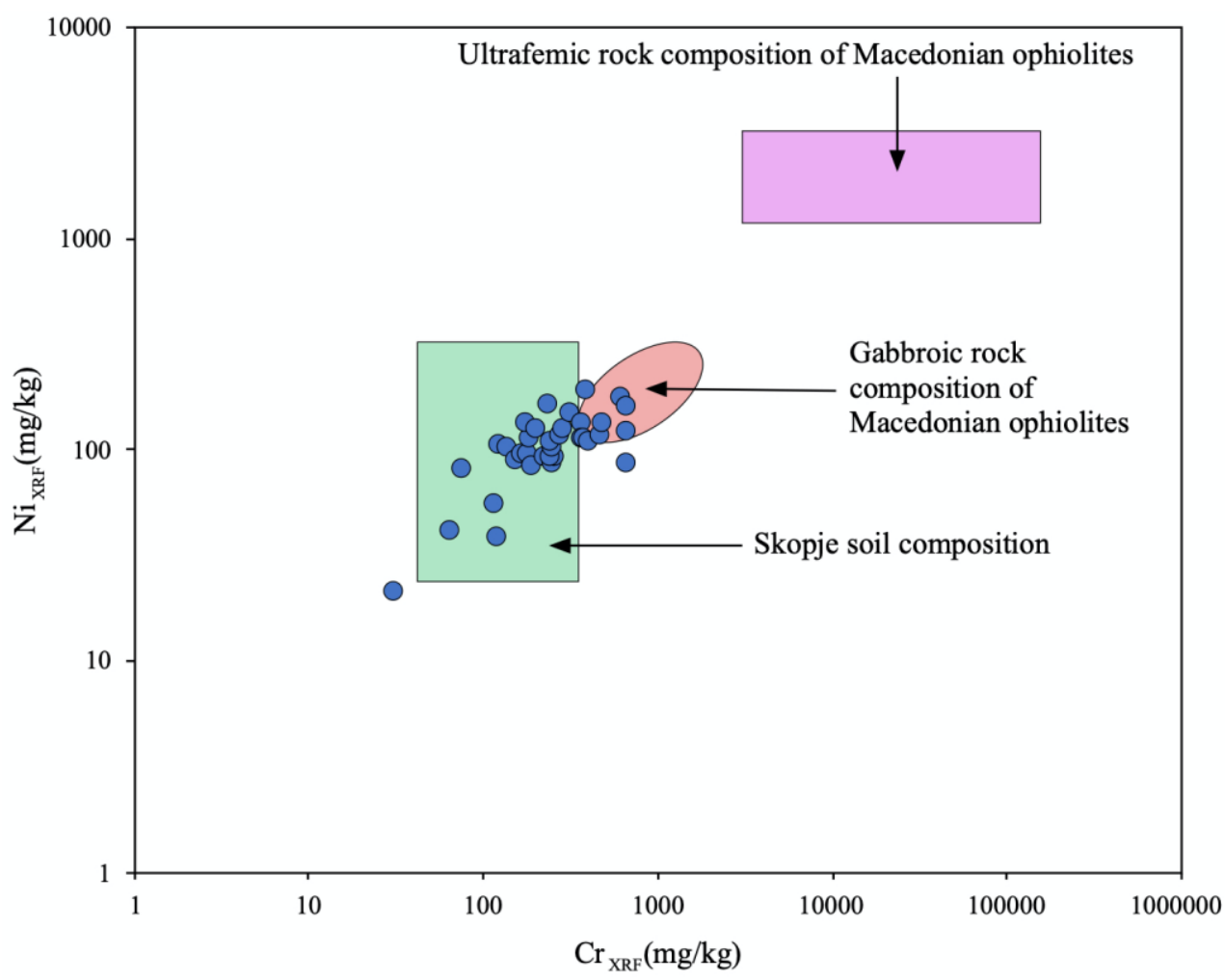

Figure 6. $\mathrm{Cr}$ vs $\mathrm{Ni}$ contents in $\mathrm{C} \& \mathrm{D}$ waste samples compared with $\mathrm{Cr}-\mathrm{Ni}$ contents of i) Skopje soil [30]; ii) ultrafemic [25] and gabbroic rock [26] compositions of ophiolitic complexes.

Apart from the origin, are such elements dangerous for human health and environment, and do they preclude the recycling of the Macedonian C\&D waste? To assess the "real" potential risk of C\&D waste, the mobility of heavy metals must also be taken into account [31,32]. Considering that dump sites are "open systems" exposed to the atmospheric condition (e.g., rainfall), we applied leaching tests in the assessment of worst case environmental scenarios, i.e., when elements of the samples become soluble and mobile in water. The leaching tests presented in this work were based on UNI EN 12457- Part 2 (2004) methodology [33] for leaching of granular waste materials, required by the Italian Ministerial Decree $n^{\circ} 186$ of $5^{\text {th }}$ of April 2006 (Italian Law D.M. 186/2006 [34]) for the recovery of non-hazardous waste. The analytical procedure of UNI EN 12457-Part 2 (2004) [33] prescribed one stage $24 \mathrm{~h}$-batch test at a liquid to solid ratio (L/S) of 10:1. A similar procedure was applied to twelve C\&D samples, showing high XRF content of $\mathrm{Cr}(>350 \mathrm{mg} / \mathrm{kg})$ and one sample with high XRF content of $\mathrm{Pb}(265 \mathrm{mg} / \mathrm{kg})$. We performed one stage 24 h-batch test at $\mathrm{L} / \mathrm{S} 10: 1$, using deionised water and finely powdered C\&D waste samples. The results of ICP-MS analyses on leachates were compared with the Italian TVHM concerning the reuse of not dangerous wastes as inert material $[34,35]$ (Table S4). The concentration of most metals in C\&D leachates was below the considered Italian TVHM limits, despite that the same samples had XRF concentrations exceeding the Italian, Chinese, and Dutch TVHMs. The only exceptions were i) $\mathrm{Cr}$, as 8 out of $13 \mathrm{C} \& \mathrm{D}$ waste sample leachates had concentrations higher than the respective Italian TVHM (even 12 times higher in AF39; Figure 7a), and, to a lesser extent ii) $\mathrm{Ni}$, since 3 out of $13 \mathrm{C} \& \mathrm{D}$ waste sample leachates had concentrations higher than the respective Italian TVHM (Figure $7 b$ ), as well as, iii) $C u$, as only one $C \& D$ waste sample exceeded the respective Italian TVHM (not shown). The analyses suggest that $\mathrm{Cr}$ (and $\mathrm{Ni}$ ) contamination risk should not be underestimated, therefore $\mathrm{C} \& \mathrm{D}$ waste recycling must be assessed thoroughly, and eventually, also the planning of periodic chemical analyses as measures for providing security must be considered. 


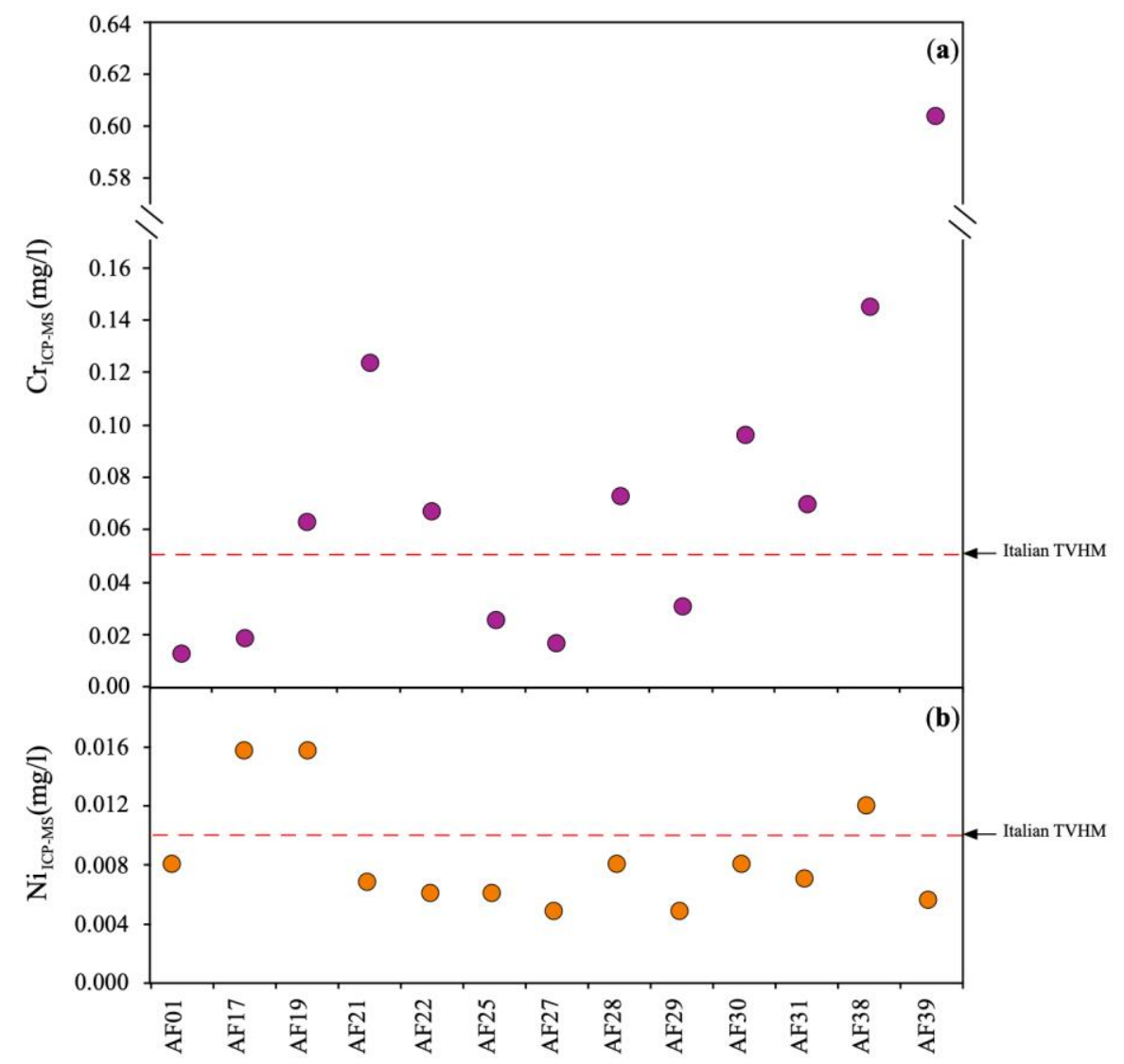

Figure 7. Concentrations in $\mathrm{mg} / \mathrm{l}$ of $\mathrm{Cr}(\mathbf{a})$ and $\mathrm{Ni}(\mathbf{b})$ in selected $\mathrm{C} \& \mathrm{D}$ waste sample leachates compared with the Italian threshold values of heavy metals (TVHM) concerning the reuse of not dangerous wastes as inert materials. Italian TVHM are from Italian Law Ministerial Decrees 5/2/98 [35] and 186/2006 [34] (Table S4).

\section{Conclusions}

The SAMCODE project allowed a survey of C\&D dump sites in Skopje city and its surroundings, and the collected samples were-for the first time-characterised from the chemical point of view.

XRF major element analysis shows that the investigated C\&D waste samples are dominated by $\mathrm{SiO}_{2}, \mathrm{CaO}$, and $\mathrm{Al}_{2} \mathrm{O}_{3}$, indicating that the original raw materials were formed by various proportions of quartz, carbonates, and clay minerals, i.e., valuable resources that can be recycled for a wide spectrum of activities. The real reuse of these materials is, however, hampered by a lack of homogeneity, an essential requisite for most applications. Moreover, a further critical aspect is highlighted by the XRF trace element analysis including hazardous heavy metals $(\mathrm{Co}, \mathrm{Cr}, \mathrm{Cu}, \mathrm{Ni}, \mathrm{Pb}, \mathrm{V}$, and $\mathrm{Zn}$ ) which revealed concentrations of $\mathrm{Cr}, \mathrm{Ni}$, and $\mathrm{Zn}$ higher than thresholds usually tolerated for environmental matrices. Such enrichments are plausibly geogenic, as $\mathrm{Cr}$ and $\mathrm{Ni}$ are abundant in Macedonian ophiolitic rocks, whereas sulphides containing $\mathrm{Zn}$ are widespread in mining areas of the country. This is also corroborated by the high $\mathrm{Cr}, \mathrm{Ni}$, and $\mathrm{Zn}$ contents recorded in Macedonian soils. Leaching tests were carried out to evaluate the mobility of these elements, and the ICP-MS analysis highlights that leachates have compositions of $\mathrm{Cr}$ (and subordinately of $\mathrm{Ni}$ ) exceeding legislative thresholds concerning reuse of waste materials, suggesting that the Macedonian C\&D waste recycling must be considered carefully due to the $\mathrm{Cr}$ (and $\mathrm{Ni}$ ) risk contamination.

To a broader vision, the message of this project is that $C \& D$ waste recycling is important and feasible; but it must be performed following guidelines to guarantee human safety and low environmental impacts. A few collecting centres should be planned, and dumped materials should be transferred 
to these centres. In such collecting centres a strict protocol should be followed: i) Registration of the provenance of incoming material; ii) elimination of hazardous components for human health (i.e., metal oxides, sulphides, asbestos, etc.) before the $C \& D$ processing; iii) homogenization of $C \& D$ waste via sorting, crushing, and grain size selection, and; iv) periodical chemical/mineralogical analyses to prevent heavy metals contamination. Nowadays, this approach is not followed in the Republic of Macedonia, therefore it is important to sensitise the operators of building activities as well as local politicians on the correct solid waste management and the importance of $C \& D$ waste recycling.

Supplementary Materials: The following are available online at http://www.mdpi.com/2071-1050/12/5/2055/s1, Table S1: Sampling coordinates and volume of C\&D waste in dump sites of Skopje and its surroundings (Republic of Macedonia), Table S2: Total carbon (TC, wt.\%), total organic carbon (TOC, wt.\%), total inorganic carbon (TIC, wt.\%), and total nitrogen (TN) composition of the investigated C\&D waste samples, Table S3: XRF major (oxide wt.\%) and trace element $(\mathrm{mg} / \mathrm{kg}$ ) composition of C\&D waste samples and Italian, Chinese, and Dutch threshold values of heavy metals (TVHM) for quality of soils, Table S4: ICP-MS trace element composition of C\&D waste sample leachates $(\mathrm{mg} / \mathrm{l})$ and Italian TVHM concerning the reuse of not dangerous wastes as inert material.

Author Contributions: Conceptualization, G.B., I.R. and I.M.; methodology, A.Z., C.N., G.M.S., C.M. and A.F.; writing-review and editing, G.B. and V.B.; project administration and funding acquisition, G.B., I.R. and I.M. All authors have read and agreed to the published version of the manuscript.

Funding: This research was funded by the Know-How Exchange Program of the Central European Initiative "SAMCODE" (Project reference number 1206.008-17).

Acknowledgments: The authors are grateful to Elisabetta Dovier of the Central European Initiative for her assistance during the project, to Adnan Ajrula and Mrs. Emilija Gjurcinovska Matevska of the Gazi Baba Municipality for their encouragement in the research, to Lena Talevska and Mario Pislevski for their help in crushing samples at IECE and to Renzo Tassinari, who is responsible for the XRF and ICP-MS laboratories at the Department of Physics and Earth Sciences. The authors also thank the Editorial Office and two anonymous reviewers for their constructive criticism and suggestion.

Conflicts of Interest: The authors declare no conflict of interest.

\section{References}

1. Blengini, G.A.; Garbarino, E. Resources and waste management in Turin (Italy): The role of recycled aggregates in the sustainable mix. J. Clean. Prod. 2010, 18, 1021-1030. [CrossRef]

2. De Melo, A.B.; Goncalves, A.F.; Martins, I.M. Construction and demolition waste generation and management in Lisbon (Portugal). Resour. Conserv. Recycl. 2011, 55, 1252-1264. [CrossRef]

3. Mercedes, R.M.; Pilar, I.G.; Isabel, S.W.A. Sustainable construction: Construction and demolition waste reconsidered. Waste Manag. Res. 2009, 28, 118-129. [CrossRef]

4. Borghi, G.; Pantini, S.; Rigamonti, L. Life cycle assessment of non-hazardous Construction and Demolition Waste (CDW) management in Lombardy Region (Italy). J. Clean. Prod. 2018, 184, 815-825. [CrossRef]

5. Bianchini, G.; Marrocchino, E.; Tassinari, R.; Vaccaro, C. Recycling of construction and demolition waste materials: A chemical-mineralogical appraisal. Waste Manag. 2005, 25, 149-159. [CrossRef]

6. European Parliament. Directive 2008/98/CE of the European Parliament and of the Council of 19 November 2008 on Waste and Repealing Certain Directives. Off. J. Eur. Union 2008, L312, 3-30.

7. Christensen, T.H.; Birgisdottir, H. Recycling of construction and demolition waste. In Solid Waste Technology and Management, 1st ed.; Christensen, T.H., Ed.; Blackwell Publishing Ltd.: Oxford, UK, 2011; Volume 2, pp. 243-249.

8. Ristovski, I.; Milcov, I.; Zupanc, A.; Bianchini, G.; Natali, C.; Salani, G.M. Methodology for C\&D waste collection and disposal and associated greenhouse gas emissions: Experiences from project SAMCODE in Skopje planning region. In Proceedings of the 6th Edition of European Conference on Water, Waste and Energy Management, Stockholm, Sweden, 13-14 May 2019.

9. Limbachiya, M.; Marrocchino, E.; Koulouris, A. Chemical-mineralogical characterisation of coarse recycled concrete aggregate. Waste Manag. 2007, 27, 201-208. [CrossRef]

10. Dimovska, S.; Stafilov, T.; Sajn, R. Radioactivity in soil from the city of Kavadarci (Republic of Macedonia) and its environs. Radiat. Prot. Dosimetry 2012, 148, 107-120. [CrossRef] 
11. Stojanovska, Z.; Boev, B.; Bossew, P.; Ristova, M.; Dimov, G.; Boev, I.; Zunic, Z.S. Analysis of specific radionuclide activity variations in soil within geotectonic units of Republic of North Macedonia. Nuclear Technol. Radiat. Prot. 2019, 34, 85-93. [CrossRef]

12. Natali, C.; Bianchini, G.; Carlino, P. Thermal stability of soil carbon pools: Inferences on soil nature and evolution. Thermochim. Acta 2020, 683, 178478. [CrossRef]

13. Lachance, G.R.; Traill, R.J. Practical solution to the matrix problem in X-ray analysis. Can. J. Spectros. 1966, $11,43-48$.

14. Kuzyakov, Y. Priming effects: Interactions between living and dead organic matter. Soil Biol. Biochem. 2010, 42, 1363-1371. [CrossRef]

15. Manning, D.A.C. Introduction to industrial Minerals, 1st ed.; Springer Science+Business: London, UK, 1995; pp. 141-158. [CrossRef]

16. Fiori, C.; Fabbri, B.; Donati, G.; Venturi, I. Mineralogical composition of the clay bodies used in the Italian tile industry. Appl. Clay Sci. 1989, 4, 461-473. [CrossRef]

17. Bianchini, G.; Martucci, A.; Vaccaro, C. Petro-archaeometric characterisation of "cotto ferrarese": Bricks and terracotta elements from historic buildings of Ferrara. Period. Mineral. 2002, 71, 101-111.

18. Morais, S.; Garcia, F.; de Lourdes Pereira, C.M. Heavy metals and human health. In Environmental Health-Emerging Issues and Practice; Oosthuizen, J., Ed.; InTech: London, UK, 2012. [CrossRef]

19. Prieto-Taboada, N.; Ibarrondo, I.; Gómez-Laserna, O.; Martinez-Arkarazo, I.; Olazabal, M.A.; Madariaga, J.M. Buildings as repositories of hazardous pollutants of anthropogenic origin. J. Hazard Mater. 2013, 248-249, 451-460. [CrossRef] [PubMed]

20. Gao, X.; Gu, Y.; Xie, T.; Zhen, G.; Huang, S.; Zhao, Y. Characterization and environmental risk assessment of heavy metals in construction and demolition wastes from five sources (chemical, metallurgical and light industries, and residential and recycled aggregates). Environ. Sci. Pollut. Res. 2015, 22, 9332-9344. [CrossRef]

21. Townsend, T.; Tolaymat, T.; Leo, K.; Jambeck, J. Heavy metals in recovered fines from construction and demolition debris recycling facilities in Florida. Sci. Total Environ. 2004, 332, 1-11. [CrossRef]

22. The Government of Italy. Legislative Decree 152/06 (2006) Norme in materia ambientale; Official Gazette n. 88; The Government of Italy: Rome, Italy, 2006. (In Italian)

23. CEPA (Chinese Environmental Protection Administration). Environmental Quality Standard for Soils (GB15618-1995); CEPA: Beijing, China, 1995. (In Chinese)

24. ESdat. Dutch Soil Remediation Circular 2009; ESdat: Ballina, NSW, Australia, 2009; Available online: http://esdat.net/Environmental\%20Standards/Dutch/ENGELSE\%20versie\%20circulaire\% 20Bodemsanering\%202009.pdf (accessed on 15 January 2020).

25. Augé, T.; Morin, G.; Bailly, L.; Serafimovsky, T. Platinum-group minerals and their host chromitites in Macedonian ophiolites. Eur. J. Mineral. 2017, 29, 585-596. [CrossRef]

26. Božović, M.; Prelević, D.; Romer, R.L.; Barth, M.; Van Den Bogaard, P.; Boev, B. The Demir Kapija ophiolite, Macedonia (FYROM): A snapshot of subduction Initiation within a back-arc. J. Petrol. 2013, 54, 1427-1453. [CrossRef]

27. Tasev, G.; Serafimovski, D.; Serafimovski, T. Evolution of ore-forming fluids in the Bukovik-Kadiica porphyry Cu deposit, Republic of Macedonia. Geologia Croatica 2018, 71, 1-18. [CrossRef]

28. Mihajlov, M.; Barandovski, L.; Šajn, R.; Stafilov, T. Spatial distribution of heavy metals in soils in the Republic of Macedonia. Geologica Macedonica 2016, 30, 41-54.

29. Puteska, A.; Dimovska1, B.; Šajn, R.; Stafilov, T. Distribution of chemical elements in soil samples from the Pelagonia region, Republic of Macedonia. Geologia Croatica 2015, 68, 261-272. [CrossRef]

30. Stafilov, T.; Šajn, R.; Ahmeti, L. Geochemical characteristics of soil of the city of Skopje, Republic of Macedonia. J. Environ. Sci. Health Part A 2019, 54, 972-987. [CrossRef] [PubMed]

31. Karim, M.R.; Kuraoka, M.; Higuchi, T.; Sekine, M.; Imai, T. Assessment of heavy metal contamination from municipal solid waste open dumping sites in Bangladesh. J. Hydrol. Environ. Res. 2014, 2, 41-49. [CrossRef]

32. Scott, J.; Beydown, D.; Amal, R.; Low, G.; Cattle, J. Landfill management, leachate generation and leach testing of solid wastes in Australia and overseas. Crit. Rev. Environ. Sci. 2005, 35, 239-332. [CrossRef]

33. Ente Nazionale Italiano di Unificazione. UNI EN 12457-Part 2 (2004)_Characterisation of Waste-Leaching-Compliance Test for Leaching of Granular Waste Materials and Sludges-Part 2: One Stage Batch Test at a Liquid to Solid Ratio of $10 \mathrm{l} / \mathrm{kg}$ for Materials with Particle Size below $4 \mathrm{~mm}$ (without or with Size Reduction); Ente Nazionale Italiano di Unificazione: Milan, Italy, 2004. 
34. The Government of Italy. Ministerial Decree n. 186 (2006) Regolamento Recante Modifiche al Decreto Ministeriale 5 Febbraio 1998 "Individuazione dei Rifiuti non Pericolosi Sottoposti alle Procedure Semplificate di Recupero, ai Sensi Degli Articoli 31 e 33 del Decreto Legislativo 5 Febbraio 1997, n. 22" (Regulatory that Modified Ministerial Decree Dated 5 February 1998); Official Gazette no. 115; The Government of Italy: Rome, Italy, 2006. (In Italian)

35. The Government of Italy. Ministerial Decree (1998) Individuazione dei Rifiuti non Pericolosi Sottoposti alle Procedure Semplificate di Recupero ai Sensi Degli Articoli 31 e 33 del D.Lgs 5 Febbraio 1997, n.22 (Identification of Non-Hazardous Waste Subject to Simplified Recovery Procedures under Articles 31 and 33 of Legislative Decree 5 February 1997 n. 22); Official Gazette no. 88; The Government of Italy: Rome, Italy, 1998. (In Italian)

(C) 2020 by the authors. Licensee MDPI, Basel, Switzerland. This article is an open access article distributed under the terms and conditions of the Creative Commons Attribution (CC BY) license (http://creativecommons.org/licenses/by/4.0/). 